\title{
Using Dispositional Surveys to Improve Individual and Program Quality in Educational Leadership
}

\author{
Dorothy C. Rea ${ }^{1}$, Cecil F. Carter, Christopher M. Parfitt, Judy R. Wilkerson, \& Thomas C. Valesky \\ Florida Gulf Coast University, USA
}

\begin{abstract}
Assessment of dispositions provides valuable information for preparing new educational leaders. By using three dispositional instruments to meet national and state standards, we assess candidates at multiple points throughout a master's degree leadership preparation program. The Educational Leader Candidate Belief Scale (ELCBS) had been previously validated, and the most recent revision focused on diversity and social justice issues. Comparing the results from the ELCBS to the expected responses, changes were made to the program and future needs were identified. In addition, results are used to provide remediation for individual students in facilitating the acquisition of dispositions. Assessment of dispositions is complex and consistent with accreditation standards and requirements for program approval, yet vital in ensuring students are able to lead inclusive schools.

Keywords: dispositions, social justice, assessment, program improvement, leadership
\end{abstract}

\section{Background and Purpose}

In this paper, we are reporting the results of our use of the Educational Leader Candidate Belief Scale (ELCBS) that was developed in 2011. We have developed three instruments to use in educational leadership preparation programs to assist with assessing candidate dispositions, and educating candidates about dispositions. These three instruments are:

1. Education Leader Candidate Belief Scale (ELCBS). Educational leadership candidates are asked whether they agree or disagree on each disposition statement. For a complete description of the validation work on this instrument, see Rea, Carter, Wilkerson, Valesky, and Lang (2011).

2. Candidate Disposition Self-Evaluation (CDSE). The second instrument is based on the Educational Leadership candidate's self-reporting of dispositions. This instrument is primarily used in our program to begin the educative process of learning about dispositions for educational leadership.

3. Mentor Evaluation of Dispositions in Educational Leadership (MEDEL). The third instrument is completed by the candidates' mentors during the internship in which the mentors assess candidates on each disposition.

The ELCBS is administered to students about half way through the program, so we can determine strengths and weaknesses of each candidate, and also to use the results to improve our program. In this paper, we report our analysis of four years of ELCBS data. We analyzed patterns of improvement in student dispositions to examine if changes in our program may have led to improvements, and we identify problems with student dispositions that need to be addressed by changes in our program. The themes of diversity and social justice were emphasized in the ELCBS based on our review of the literature, as well as a focus by the education accreditation body - Council for the Accreditation of Educator Preparation (CAEP). Katz (1993) reported that since its beginnings, the United States has worked to bring culture unity linguistically and economically to all citizens, and that there has been a struggle to meet all students' needs. We agree with the education research and theories that leaders with the proper dispositions can lead inclusive schools in which all students can reach their full potential (Theoharis \& Scanlon, 2015).

\section{Review of the Literature}

The challenge in the school systems is to educate a diverse population effectively. How do school officials meet each student's needs? The goal of the educational leadership program is to help school leaders build the capacity of their communities to meet students' diverse needs inclusively (Theoharis \& Scanlon,

${ }^{1}$ Florida Gulf Coast University, College of Education, Merwin Hall 245, 10501 FGCU Boulevard South, Fort Myers, FL 33965-6565

239-590-7777

DRea@fgcu.edu 
2015). The school leader must have the knowledge, skills, and dispositions to create and carry out a vision for an inclusive school (Demirhan, \& Yücel, 2016; Kilinç, 2017; Tarman, 2012). For example, Hall and Quinn (2014) found technology to be a tool to increase parent involvement; however, technology cannot serve as a substitute for authentic parent involvement.

In the field of educational leadership, the Interstate School Leaders Licensure Consortium (ISLLC) standards are the benchmarks for effective school leadership. Each standard is comprised of knowledge, skills, and dispositions (Council of Chief State School Officers, 1996). The ISLLC standards were revised in 2008 and named the National Educational Leadership Policy Standards (Council of Chief State School Officers, 2008a). The dispositions were enumerated in the document developed as a companion piece to the titled Performance Expectations and Indicators for Education Leaders (Council of Chief State School Officers, 2008b). This document effectively links knowledge, skills, and dispositions, asserting that:

The performance expectations and indicators exemplify fundamental assumptions, values and beliefs about what is expected of current education leaders. . . In order to maintain this emphasis in the performance expectations, underlying dispositions are listed as a reminder of importance when interpreting and operationalizing indicators. (p. 6)

The standards are organized into six Performance Expectations (PEs), each of which contains a list of dispositions, followed by several elements that include a number of indicators. We developed and validated the ELCBS using the dispositions enumerated in Performance Expectations and Indicators for Education Leaders (Rea et al., 2011; Rea, Carter, Valesky, \& Wilkerson, 2012; Rea, Carter, Valesky, \& Wang, X, 2013; Rea, Wilkerson, Carter, Parfitt, \& Valesky, 2013; Rea, Wilkerson, Carter, Valesky, \& Parfitt, 2015).

The Council for the Accreditation of Educator Preparation (CAEP, 2016) Standards apply to all educator preparation programs within a unit, including Educational Leadership. The first CAEP standard, on Content and Pedagogical Knowledge, requires evidence that candidates possess knowledge, skills, and dispositions. This standard links this requirement to the national specialty professional associations (Component 1.3) and requires that providers ensure that candidates demonstrate skills, as well as commitments (Component 1.4).

Villegas defined dispositions as "tendencies for individuals to act in a particular manner under particular circumstances, based on their beliefs" (2007, p. 373). Wilkerson and Lang (2007) identified the components of dispositions as values, beliefs, and attitudes, which influenced the use of knowledge and skills. Having the proper dispositions as an educational leader was paramount. Dispositions were an effective measure for determining future success as a school leader (Wilkerson \& Lang, 2007; Kenna \& Russell, 2015).

The dispositions that are consistent with national standards are necessary for a prospective educational leadership candidate to be successful in a leadership role. We believe that an important disposition necessary for effective leadership is the belief in inclusive schools where socially just practices benefit all students (Marshall \& Olivia, 2010; Michou, Mouratidis, Ersoy, Ugur, 2016; Tarman, 2016). To this end, we have included inclusive schools as a major theme of our leader preparation program. Our belief is widely supported in the literature. Theoharis (2007) spoke to the role of preparation programs in developing leaders who act for social justice and address the resistance that often accompanies their actions. While addressing the current education reform movement, with its market-based approach, Carpenter and Diem (2014) observed, “. . . it is important to consider how and why the preparation of socially just school leaders is needed to counteract the dominant discourses dominating educational reform" (p. 8). Normore and Brooks (2014) stated, “. . . school leaders' individual values and ethics are critical because they are uniquely positioned to influence socially just processes and outcomes in schools" (p. xiii). Giroux, (as cited in Normore \& Brooks, 2014) noted:

...the narrative of educational administration and the story of leadership need to

be rewritten to ensure that educational leaders are taught how to develop a philosophy whose purpose is to foster a democratic society that advocates for social justice within their schools and communities. (2014, p. 12)

Fostering advocacy within a democratic society has been identified as a critical component needed within educational settings. Laffer (2014) stressed an importance of educating by opening minds and becoming more human; the focus should be on the good, while striving toward perfection. In the strive toward perfection, addressing social justice issues in schools is needed to provide a supportive curriculum and raise awareness of differences in culture, gender and race (Damgaci \& Aydin, 20141; Lafer \& Aydin, 2012; Yurtseven \& Altun, 2015; Tarman \& Gürel, 2017). All of which connects to Carpenter and Diem's (2014) contention of a need to train socially just leaders for schools. Determination of future success as an educational leader can be made by assessment of a candidate's dispositions. 


\section{Methodology \\ Scale Structure}

The ELCBS was developed to assess dispositions related to national standards. Using Thurstone scaling, a candidate must select agree or disagree to each statement. Items are based on Bloom, Krathwohl, and Masia's Affective Taxonomy, and use the Rasch model of item-response theory to yield valid and reliable results. ELCBS has been updated to reflect changes in the standards (Rea, Wilkerson et al., 2013). A greater focus on social justice was emphasized during revisions (Rea, Carter, Valesky, Wilkerson, \& Parfitt, 2014). With each change, the instrument was validated for the intended purpose. Using Lawshe's (1975) Content Validity Ratio (CVR), a panel of experts including practicing school administrators and university faculty reviewed each item as essential, observable, and standards-based (see Wilkerson et al., 2016 for validity \& reliability results). For each item, a CVR was calculated, and all items were found to have content validity. Analysis through WinSteps yielded a Cronbach's Alpha of .76 for person reliability (Wilkerson et al., 2016). In the ELCBS, we have written items that indicate whether student beliefs are consistent with national standards. To ensure that students do not always select agree or disagree, we have a mix of items for these two response options. Items are scored as to whether they meet expectations related to the standard and the Krathwohl et al. affective taxonomy. If it is consistent, we call it the "expected" response, and the expected response might be either "agree" or "disagree."

Here are two examples from PE3, which is: Educational leaders ensure the success of all students by managing organizational systems and resources for a safe, and high-performing learning environment.

Example Number 1: Item PE3-8 reads, "School principals should address teachers' personal problems even if it takes time away from working with them on their teaching skills." We expect principals to ensure that teachers' personal problems do not interfere with their ability to work effectively for the creation of a safe and high-performing learning environment, so the expected response is "agree."

Example Number 2: Item PE3-4 reads, "Leaders should take responsibility for making most major decisions rather than delegating responsibility." We expect the principal to delegate management responsibilities for decision making to maximize input and buy-in, so the expected response is "disagree."

\section{Research Questions}

1. How have student responses on the ELCBS changed over time (three years)?

2. Do students' dispositions improve when dispositions are explicitly taught?

\section{Data Analysis}

We grouped student responses on the ELCBS from 2011- $2012(n=41)$ and 2014-2015 $(n=16)$. We then compared the percentages of responses that were as expected between the two groups. We examined the changes for each of the questions, which span the six Performance Expectations.

The ELCBS contains a total of 53 items. From these 53 items, the percentage of responses that were as expected for 23 items increased, the percentage of responses that were not as expected decreased for another 21 items, and the percentage of responses that were as expected remained the same for nine items. However, for practical application, we determined that items with less than a $10 \%$ increase or decrease were not useful for our analysis, so we only reviewed items for which the expected response increased or decreased by at least $10 \%$.

There were 17 items that met this criterion and remained in our analysis. For six items, we found a decrease in the percentage of items receiving the expected response, and 11 items that showed an increase in receipt of the expected response. This meant for us that we have 11 items on which we can celebrate improvement based on our instructional efforts and six that will become the target for improvement.

Of the six items for which expected responses showed a decrease (need for improvement), each was from a different Performance Expectation; that is, there was only one from each PE. These items are listed in Table 1, and the item number reflects the relevant PE and sequence in the scale. 
Table 1.

Items for Which the Percent of Expected Responses Decreased Over Time

\begin{tabular}{|c|c|c|c|}
\hline $\begin{array}{l}\text { Item } \\
\text { Number }\end{array}$ & Item & $\begin{array}{l}\text { Expected } \\
\text { Response }\end{array}$ & $\begin{array}{l}\% \text { Change in } \\
\text { Responses }\end{array}$ \\
\hline PE1-2 & $\begin{array}{l}\text { Consensus is critical in setting a vision, but sometimes one } \\
\text { or two people can get in the way. }\end{array}$ & Disagree & $-16 \%$ \\
\hline PE2-2 & $\begin{array}{l}\text { Diversity in classrooms is a major problem in developing } \\
\text { appropriate learning opportunities. }\end{array}$ & Disagree & $-10 \%$ \\
\hline PE3-8 & $\begin{array}{l}\text { School principals should address teachers' personal problems } \\
\text { even if it takes time away from working with them on their } \\
\text { teaching skills. }\end{array}$ & Agree & $-31 \%$ \\
\hline PE4-4 & Email is the best way to communicate with parents. & Disagree & $-10 \%$ \\
\hline PE5-7 & $\begin{array}{l}\text { Reflection is an essential part of my job, even if the time it } \\
\text { takes risks aggravating my family members. }\end{array}$ & Agree & $-11 \%$ \\
\hline PE6-5 & I allow children to pray in the beginning of the school day. & Disagree & $-18 \%$ \\
\hline
\end{tabular}

The three Performance Expectations from the Interstate Leaders Licensure Consortium (ISLLC) Standards that had the most change were PE 3, 4, and 5. The Performance Expectations are all provided below:

PE3 is: Educational leaders ensure the success of all students by managing organizational systems and resources for a safe, and high-performing learning environment.

PE4 is: Educational Leaders ensure the success of all students by collaborating with families and stakeholders who represent diverse community interests and needs and mobilizing community resources that improve teaching and learning.

PE5 is: Educational Leaders ensure the success of all students by being ethical and acting with integrity.

The faculty will address these particular items in specific classes:

- $\quad$ PE1 (item 2): Organizational Development

- $\quad$ PE2 (item 2): Principles of Educational Leadership; Instructional Leadership

- $\quad$ PE3 (item 8): Human Resources Development

- $\quad$ PE4 (item 4): Organizational Development

- PE5 (item 7): Organizational Development

- $\quad$ PE6 (item 5): School Law

In addition, all of the above are addressed in Internships I and II. Assignments will include reflective activities, such as individual written work, and large and small group discussions. We will create curriculum and follow explicit teaching for each of the dispositions that these items represent in the aforementioned classes (Theoharis \& Causton-Theoharis, 2008). For example, according to ISLLC Performance Indicator, "An education leader promotes the success of every student by understanding, responding to, and influencing the political, social, economic, legal, and cultural context." In the School Law course, attention is given to church-state relations and issues including prayer in schools. This issue can be confusing inasmuch as student voluntary prayer does pass constitutional muster, whereas state-sanctioned prayer, endorsed by school officials, does not. It appears that students may not fully understand this distinction. Activities that provide additional clarity will be introduced into the course.

The items with percentages of expected responses that increased by at least $10 \%$ are listed in Table 2. 
Table 2.

Items for Which the Percent of Expected Responses Increased Over Time

\begin{tabular}{|c|c|c|c|}
\hline $\begin{array}{l}\text { Item } \\
\text { Number }\end{array}$ & Item & $\begin{array}{l}\text { Expected } \\
\text { Response }\end{array}$ & $\begin{array}{l}\% \text { Change in } \\
\text { Responses }\end{array}$ \\
\hline PE1-3 & $\begin{array}{l}\text { Equal resources and opportunities should result in high } \\
\text { achievement for all children. }\end{array}$ & Disagree & $11 \%$ \\
\hline PE2-9 & $\begin{array}{l}\text { If all teachers used high quality research and data-based } \\
\text { strategies and practices, all students would succeed } \\
\text { academically. }\end{array}$ & Agree & $21 \%$ \\
\hline PE3-2 & $\begin{array}{l}\text { Resources, such as people and money, should be allocated } \\
\text { based on student need. }\end{array}$ & Agree & $24 \%$ \\
\hline PE3-4 & $\begin{array}{l}\text { Leaders should take responsibility for making most major } \\
\text { decisions rather than delegating responsibility. }\end{array}$ & Disagree & $19 \%$ \\
\hline PE3-6 & $\begin{array}{l}\text { Parents should be involved in developing the school's } \\
\text { discipline plan. }\end{array}$ & Agree & $25 \%$ \\
\hline PE4-6 & $\begin{array}{l}\text { Principals should reach out to business and community } \\
\text { members to establish school policy. }\end{array}$ & Agree & $20 \%$ \\
\hline PE4-8 & $\begin{array}{l}\text { It is the principal's responsibility to conduct research on the } \\
\text { characteristics of the community. }\end{array}$ & Agree & $14 \%$ \\
\hline PE5-4 & $\begin{array}{l}\text { You should report a fellow principal who is not following state } \\
\text { or district rules. }\end{array}$ & Agree & $18 \%$ \\
\hline PE5-5 & $\begin{array}{l}\text { Before reporting a colleague who violates the ethical code, } \\
\text { you should just talk to them and see if they change their ways. }\end{array}$ & Disagree & $20 \%$ \\
\hline PE5-8 & It is okay to go to the gym at lunch hour to work out. & Agree & $13 \%$ \\
\hline PE6-6 & $\begin{array}{l}\text { The principal should spend time in Tallahassee to influence } \\
\text { policy-makers. }\end{array}$ & Agree & $18 \%$ \\
\hline
\end{tabular}

In analyzing the items with increases in the expected responses over time, we can attribute this success to the following topics or emphases that were added to our courses:

1. The difference between equal resources and equitable resources (PE1-3; PE3-2).

2. A focus on using research and data-based strategies (PE2-9; PE4-8).

3. An emphasis on distributed leadership (PE3-2; PE3-6; PE4-6).

4. A focus on ethical principles of conduct (PE5-4; PE5-5; PE5-8).

5. An emphasis on the principal's responsibility in policy development and implementation (PE6-6).

\section{Discussion}

\section{Implications}

Items for which dispositions were explicitly taught by faculty showed an increase in ELCBS responses. Because the most recent revisions of the ELCBS focused on social justice (Rea et al., 2014), many of the items with increased scores focused on providing equitable educational opportunities for all students. However, a question pertaining to diversity increases had a 10\% decrease. Therefore, faculty will continue to be cognizant of addressing social justice issues continually. Theoharis and Causton-Theoharis (2008) provided a recommendation to increase the use of reflective activities and group discussions to facilitate the acquisition of dispositions (Wilkerson \& Lang, 2007).

The belief in using e-mail as the most effective communications method to reach parents was another area identified for improvement. While technology may provide additional avenues for communication with parent, it cannot replace personalized forms of communication. Plus, all parents do not possess access to the requisite devices or have the skills to capitalize on use of electronic forms of communication. Despite the convenience, many parents still preferred a phone call to an e-mail (Hall \& Quinn, 2014).

\section{Further Research}

Because this article focused on the results from changes made in one educational leadership program, several recommendations for future research are included: 
1. Continuation of the longitudinal analysis to determine if additional changes made after publication of the results reflect increased scores.

2. Expand the use of the ELCBS to other leadership programs.

3. Examine students' responses from the CDSE and changes between administration and completion of the ELCBS.

4. Examine changes from ELCBS scores to MEDEL scores at the completion of the program.

\section{Conclusions}

To address the first research question, we examined how our students performed over time on one of our instruments (ELCBS) that measures their beliefs on leadership dispositions. Overall, our students have performed better on a greater number of items (11 items) when compared to items in which they performed less well (six items). The improvements are directly correlated to changes in topics and emphasis for specific courses throughout the program of study.

When analyzing if students' dispositions improve with explicit instruction, as the second research question. The growth is evident, and can be attributed to changes that have been made to our program to help improve student dispositions. Facilitating the acquisition of dispositions is complex, and cannot be accomplished in one session; educational leadership programs should be based on deliberate and continuous exposure to accepted dispositions throughout the program, and accepted dispositions include a belief in inclusive schools as the bedrock of successful schools.

The process for continuous program improvement is endless. Because student scores decreased in six areas, we will focus attention on the dispositions represented in the items that decreased over time, and re-examine student responses in the future. Explicit instruction helps students foster positive dispositions, which will ultimately benefit K-12 students; therefore, the practice should be strengthened. This type of program analysis and improvement is in concert with the requirements of our accreditation body, CAEP. Continuous program improvement based on data, such as presented in this article will not only meet accreditation standards, but will also help our students become better school administrators.

\section{References}

Carpenter, B. W., \& Diem, S. (2014, April). Guidance matters: A critical discourse analysis of the racerelated policy vocabularies shaping leadership preparation. Urban Education, 1-20. doi:10.1177/0042085914528719.

Citamak, Y. \& Yigit, H., I. (2012). From Student's Table to Teacher's Desk. International Journal of New Trends in Arts, Sports \& Science Education, 1(2), 1-7.

Council for the Accreditation of Educator Preparation (2015). CAEP accreditation manual. Washington, DC: Author. Retrieved from http://caepnet.org/standards/

Council of Chief State School Officers (1996). Interstate School Leaders Licensure Consortium standards for school leaders. Washington, DC: Author.

Council of Chief State School Officers (2008a). Educational leadership policy standards. Washington, DC: Author.

Council of Chief State School Officers (2008b). Performance expectations and indicators for educational leaders. Washington, DC: Author.

Damgaci, F. K., \& Aydin, H. (2014). An analysis of academicians' perceptions of multicultural ducation: A Turkish experience. The Anthropologist, 18(3), 817-833.

Demirhan, G., \& Yücel, C. (2016). A Prediction for Teacher Commitment: Effects of Managerial Style, Burnout and Demographics, Research in Social Sciences and Technology, (I)1, 24-43,

Hall, N., \& Quinn, R. J. (2014). Parental involvement at the high school level: Parents' perspectives. Journal of Ethnic and Cultural Studies, 1(1), 13-21.

Katz, L. G. (1993). Dispositions: Definitions and implications for early childhood practice. Retrieved from http://ceep.crc.uiuc.edu/eecearchive/books/disposit.html

Kenna, J. L., \& Russell, W. B. (2015). Secondary social studies teachers' time commitment when addressing the common core state standards. Journal of Social Studies Education Research, 6(1), 26-48. doi:10.17499/jsser.37219

Kilinc, E. (2017). Review of modernising school governance: Corporate planning and expert handling in state education. New York, NY: Routledge. 172 pp., ISBN-9781138787476. Research In Social Sciences And Technology, 2(2). Retrieved from http://ressat.org/index.php/ressat/article/view/327 
Lafer, S. \& Aydin, H. (2012). Educating for Democratic Societies: Impediments. Journal of Social Studies Education Research, 3 (2), 45-70. Retrieved from http://dergipark.gov.tr/jsser/issue/19099/202681

Lafer, S. (2014). Democratic design for the humanization of education. Journal of Ethnic and Cultural Studies, 1(1), 6-12.

Lawshe, C. H. (1975). A quantitative approach to content validity. Personnel Psychology, 28, 563-575. doi:10.1111/j.1744-6570.1975.tb01393

Marshall, C. \& Oliva, M. (2010). Leadership for social justice: Making revolutions in education ( $2^{\text {nd }}$ ed.). Boston, MA: Allyn and Bacon.

Michou, A., Mouratidis, A., Ersoy, E., \& Uğur, H. (2016). Social achievement goals, needs satisfaction, and coping among adolescents. Personality and Individual Differences, 99, 260-265.

Normore, A. H., \& Brooks, J. S. (Eds.). (2014). Educational leadership for ethics and social justice: Views from the social sciences. Charlotte, NC: Information Age.

Rea, D. C., Carter, C. F., Wilkerson, J. R., Valesky, T. C., \& Lang, W. S. (2011). Assessing ISLLC-based dispositions of educational leadership candidates. International Journal of Educational Leadership, 69(3), 1-15.

Rea, D. C., Carter, C. F., Valesky, T. C., \& Wilkerson, J. R. (2012, September). Assessing prospective school leaders' dispositions. Paper presented at the meeting of the Southern Regional Council on Educational Administration, New Orleans, LA.

Rea, D. C., Carter, C. F., Valesky, T. C., \& Wang, X. (2013, February). Scaling educational leadership candidates' commitment to the ISLLC standards: The ELCBS scale. Paper presented at the meeting of the Eastern Educational Research Association, Sarasota, FL.

Rea, D. C., Carter, C. F., Valesky, T. C., Wilkerson, J. R., \& Parfitt, C. M. (2014, October). Incorporating social justice in the educational leadership candidate belief survey. Paper presented at the meeting of the Southern Regional Council on Educational Administration, Atlanta, GA.

Rea, D. C., Wilkerson, J. R., Carter. C. F., Parfitt, C. M., \& Valesky, T. C. (2013, October). Measuring educational leadership dispositions based on multiple theories. Paper presented at meeting of the Southern Regional Conference on Educational Administration, Oklahoma City, OK.

Rea, D. C., Wilkerson, J. R., Carter, C. F., Valesky, T. C., \& Parfitt, C. M. (2015, November). Validating a survey to assess dispositions in educational leadership using the 2015 draft ISLLC Standards. Presentation at the meeting of the Southern Regional Council on Educational Administration, Atlanta, GA.

Tarman, B. (2012). Effective Leadership in Culturally Diverse Schools, Energy Education Science and Technology Part B: Social and Educational Studies, 4(2) 1103-1114.

Tarman, B. (2016). Innovation and education. Research in Social Sciences and Technology, 1(1), 77-97.

Tarman, B.\& Gürel, D. (2017). Awareness of social studies teacher candidates on refugees in Turkey. The Journal of Social Studies Research, http://dx.doi.org/10.1016/j.jssr.2016.11.001i

Theoharis, G. (2007). Social justice educational leaders and resistance: Toward a theory of social justice leadership. Educational Administration Quarterly, 43(2), 221-258. doi:10.1177/0013161X06293717

Theoharis, G., \& Causton-Theoharis, J. (2008). Oppressors or emancipators: Critical dispositions for preparing inclusive school leaders. Equity \& Excellence in Education, 41(2), 230-246. doi:10.1080/10665680801973714

Theoharis, G., \& Scanlon, M. (Eds.). (2015). Leadership for increasingly diverse schools. New York, NY: Routledge.

Villegas, A. M. (2007). Dispositions in teacher education: A look at social justice. Journal of Teacher Education, 58(5), 370-380. doi:10.1177/0022487107308419

Wilkerson, J. R., \& Lang, W. S. (2007). Assessing teacher dispositions: Five standards-based steps to valid measurement using the DAATS model. Thousand Oaks, CA: Corwin Press.

Wilkerson, J. R., Rea, D. C., Valesky, T. C., Carter, C. F., Parfitt, C. M., Lang, W. S., Hartman, J., Permuth, S., \& Shapiro, A. (2016, February). Educational leader candidate belief scale: A validity study. Paper presented at the meeting of the Eastern Educational Research Association, Hilton Head, SC.

Yurtseven, N., \& Altun, S. (2015). Intercultural sensitivity in today's global classes: pre-service teachers' perceptions. Journal of Ethnic and Cultural Studies, 2(1), 49-54. 